\title{
Students' Environmental Insights on Behavior of Climate Change Mitigation
}

\author{
Dwi Atmanto ${ }^{*}$, Neneng Siti Silfi Ambarwati ${ }^{2}$, Nurul Hidayah ${ }^{3}$, Esti Suntari ${ }^{4}$ \\ \{dwiatmanto64@gmail.com ${ }^{1}$,neneng_ambarwati@yahoo.co.id ${ }^{2}$,nrl.hdy@gmail.com ${ }^{3}$, \\ esti_suntari@yahoo.com ${ }^{4}$ \} \\ *corresponding author \\ Department of Cosmetology, Faculty of Engineering, Jakarta State University \\ Jalan Rawamangun Muka, Jakarta Timur, DKI Jakarta. 13220, Indonesia ${ }^{1,2,3}$ \\ Department of Management, Faculty of Economics, Pamulang University, Jalan Surya Kencana No.1 \\ Pamulang Barat Tangerang Selatan Banten, Indonesia ${ }^{4}$
}

\begin{abstract}
Students' responsibility for the environment is still low and will have an impact on the future of the earth's environment. The purpose of this study was to obtain an overview of the relationship between environmental insight and student behavior in climate change mitigation. The research method used is correlational quantitative survey method. Data obtained through questionnaires and interviews. The sample of students in this study was 60 people from various study programs at the Jakarta State University who were taken randomly. Analysis and interpretation of data shows that there is a positive relationship between students' knowledge of environmental knowledge with climate change mitigation behavior. There is a positive relationship between responsibilities for environmental preservation with student behavior about climate change mitigation. There is a positive relationship between environmental knowledge and environmental conservation responsibility by way of climate change mitigation of students behavior with $\mathrm{R}$ is 0.883 and $\mathrm{R}_{\text {square }}$ is 0.780 .
\end{abstract}

Keywords: Environmental Insights, Mitigation Behavior, Climate Change, responsibility for environmental preservation

\section{Introduction}

The population in Indonesia, especially at the productive age, is increasing and the number of students in each university is also increasing. This indicates that the younger generation is thirsty for broad insights and has the desire to continue to higher education levels [1]. The democratic climate in the country of Indonesia provides freedom and openness of opinion to support the community to give aspirations, especially to intellectuals or students [2]. Students have a big role in preserving and protecting the environment. The presence of natureloving student groups in every university is a proof of students' concern for environmental damage recently $[3,4]$. Not only students who love nature have a big responsibility in protecting and managing the environment, but the surrounding community must also participate in meeting the needs of future generations [5]. Environmental protection and conservation can be realized by carrying out positive activities such as cutting trees selectively, disposing of garbage in its place, sorting between organic and non-organic waste and carrying out waste recycling activities, minimizing the use of vehicles, the effect of greenhouse gases and other items that can pollute. Environment and cause the ozone layer to be damaged, so that air temperatures will increase and accelerate global climate change. [6, 7]. Students also collaborate with 
environmental monitoring bodies such as Environmental Impact Analysis by conducting studies on the significant impacts of a business plan and / or activity on the environment required for the decision-making process regarding the operation of a business and / or activity. (Law No. 32 of 2009 concerning Protection and Management) [3]. Support from the government is also very important to realize this environmental insight. [6] With the socialization activities carried out by students to the community about the environment, it is hoped that it can make people aware of the importance of protecting, preserving, and managing the environment [8]. However, not many students care about climate change (mitigation) efforts. In fact, climate change on earth has resulted in extreme weather $[9,10]$ and has had an impact on environmental damage $[11,12]$.

The impact of industrial and technological developments has also resulted in many students being less attentive in dealing with various environmental problems. If this is not anticipated during the educational process, students' responsibility for the environment is still low and will have an impact on the future of the earth's environment. Environmental insight can be explained as a person's perspective on environmental problems based on ecology and environmental balance in order to remain sustainable [13]. This perspective includes knowledge in the field of environment and community responsibility for the preservation of its ecosystem. To increase responsibility in environmental preservation, students need to protect and plant according to the needs and interests of the community safely without disturbing the environment. Environmental preservation pays close attention to the preservation of environmental functions both ecologically and socially [12, 13]. With a maintained environmental function, it is able to support the life of the living things in it. Therefore, environmental preservation cannot be separated from human actions in saving environmental components from threats of environmental damage such as climate change [7]. The responsibility of young people to climate change can be done by adjusting the lifestyle they live, and being more intensively involved in action to control climate change [8]. This includes the Blue Carbon initiative which is believed to be an opportunity for Indonesia to contribute more in mitigating global climate change [14].

The problems above are very urgent to conduct research on factors that can improve student behavior in mitigating climate change from small things such as choosing to buy environmentally friendly products so that they behave in an environmentally sound manner.

\section{Method}

The method used in this research is a survey method using a correlational approach. In this survey study only investigated from the population [10]. The unit of analysis in this research is students of the Cosmetology study program and the study program in the environmental family of Family Welfare Science who received the Environmental Health course. To study the same data, the researcher explains the relationship between the variables through hypothesis testing. Environmental insight includes environmental knowledge and responsibility in environmental preservation. Schematically, the problem constellation in this study can be described as figure 1 .

The target population in this study were all students of the Make Up Education Study Program and Catering Education who had been given Environmental Health courses. The affordable population is 75 students. Sources of data obtained in this study are primary data collected from the results of filling out questionnaires in response to respondents directly [11]. Respondents in this study were determined based on random sampling techniques. Samples that 
are classified as large with normal distribution are samples whose number is $>30$ samples, taken randomly. From the affordable population, 60 people were drawn randomly, while the remaining number of students $=15$ was used for instrument testing.

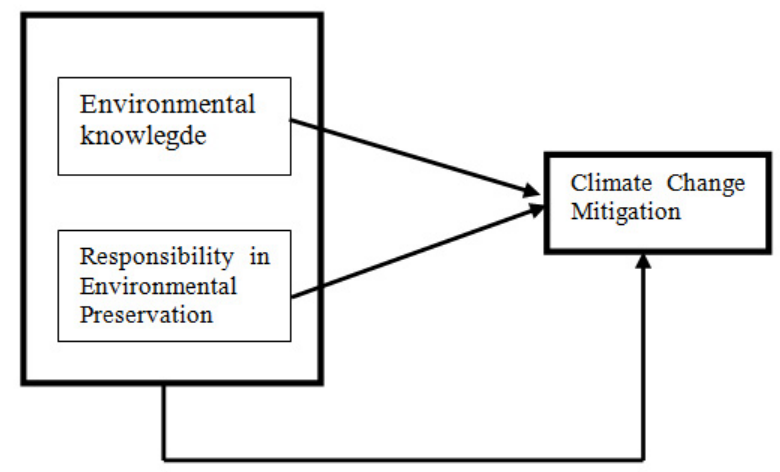

Fig.1. Relationship between variables as problem constellations Information: $\mathrm{X}_{1}=$ Environmental Knowledge; $\mathrm{X}_{2}=$ Responsibility in Environmental Preservation; $\mathrm{Y}=$ Climate Change Mitigation

\section{Results}

The data obtained from the instrument trial were then tested for validity and reliability. The research data of respondents were tested for normality and linearity. The normality test of the Environmental Knowledge variable $\left(\mathrm{X}_{1}\right)$ obtained results with a normal distribution at a price of $X_{1}=0.243$. To test the normality of the environmental conservation responsibility variable, the results are normally distributed at a price of $X_{2}=0.357$. Then the results of the normality test of climate change mitigation variable data were obtained with a normal distribution with a value of $\mathrm{Y}=0.104$.

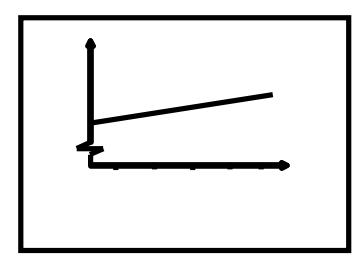

Fig,2. Graph of linearity for $\mathrm{Y}$ and $\mathrm{X}_{1}$ variables.

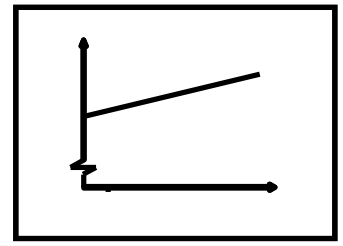

Fig.3. Linearity graph for $\mathrm{Y}$ and $\mathrm{X}_{2}$ variable

Table 1 Results of Multiple Linear Regression Analysis

\begin{tabular}{|c|c|c|c|c|c|}
\hline \multirow[t]{2}{*}{ Model } & \multicolumn{2}{|c|}{ Unstandardized Coefficients } & \multirow{2}{*}{$\begin{array}{l}\text { Standardized } \\
\text { Coefficents } \\
\text { Beta }\end{array}$} & \multirow[t]{2}{*}{$\mathrm{T}$} & \multirow[t]{2}{*}{ Sig. } \\
\hline & B & Std Error & & & \\
\hline (constant) & 25.124 & 3.885 & & 6.466 & .000 \\
\hline $\begin{array}{l}\text { Environmental } \\
\text { Knowledge }\end{array}$ & 0.165 & .105 & .271 & 2.052 & .045 \\
\hline $\begin{array}{l}\text { Responsibility of } \\
\text { Environmental } \\
\text { Preservation }\end{array}$ & 0.509 & .106 & .635 & 4.817 & .000 \\
\hline
\end{tabular}


a. Dependent variable on Climate Change Mitigation Behavior (Y)

The regression equation is $\mathrm{Y}=25.124+0.215 \mathrm{X}_{1}+0.509 \mathrm{X}_{2}$

Table 2 Results of multiple correlation analysis

\begin{tabular}{|c|c|c|c|c|c|c|c|c|c|}
\hline \multirow{2}{*}{ Model } & \multirow{2}{*}{$\mathrm{R}$} & \multirow{2}{*}{$\mathrm{R}$ square } & \multirow{2}{*}{$\begin{array}{l}\text { Adjusted } \\
\text { R square }\end{array}$} & \multirow{2}{*}{$\begin{array}{l}\text { Std. Error of } \\
\text { the Estimate }\end{array}$} & \multicolumn{5}{|c|}{ Change statistics } \\
\hline & & & & & $\begin{array}{l}\text { R Square } \\
\text { Change }\end{array}$ & $\begin{array}{l}\text { F } \\
\text { Change }\end{array}$ & $\mathrm{Df}_{1}$ & $\begin{array}{l}\mathrm{Df} \\
2\end{array}$ & $\begin{array}{l}\text { Sig. F } \\
\text { Change }\end{array}$ \\
\hline 1 & $.883^{\mathrm{a}}$ & .780 & .772 & 2.93843 & .780 & 100.846 & 2 & 57 & .000 \\
\hline
\end{tabular}

Based on the table above, the $\mathrm{R}$ number is 0.883 . This shows that there is a very strong relationship between Environmental Knowledge $\left(\mathrm{X}_{1}\right)$ and Responsibility for Environmental Conservation $\left(\mathrm{X}_{2}\right)$ on Climate Change Mitigation Behavior (Y)

Table 3 Results of the F test count

\begin{tabular}{llllll}
\hline \multicolumn{7}{c}{ ANOVA $^{\mathrm{b}}$} \\
\hline & Sum of Squares & Df & Mean Square & F & Sig. \\
\hline 1 Regression & 1741.490 & 2 & 870.745 & 100.846 & $.000^{\mathrm{a}}$ \\
Residual & 492.168 & 57 & & & \\
Total & 2233.650 & 59 & 8.634 & & \\
\hline a. & Predictors (Constant), knowledge of ecosystem, Responsibility of environmental Preservation. \\
b. & Dependent Variable: climate change mitigation.
\end{tabular}

The steps for carrying out the F test are as follows: formulating a hypothesis

Ho: there is no significant influence between environmental knowledge (insight) $\left(\mathrm{X}_{1}\right)$ and environmental conservation responsibility $\left(\mathrm{X}_{2}\right)$ together on climate change mitigation behavior (Y).

$\mathrm{H} 1$ : There is a significant influence between environmental knowledge (insight) $\left(\mathrm{X}_{1}\right)$ and environmental conservation responsibility $\left(\mathrm{X}_{2}\right)$ together on climate change mitigation behavior $(\mathrm{Y})$.

Based on the Table 3, it is obtained that F count is 100,846 with a sig level of 0.000 . If $\operatorname{sig}>$ 0.05 then Ho is rejected. With a value of $\mathrm{R}=0.883$, it shows that the two variables of environmental knowledge and student responsibility for environmental conservation have a strong relationship to climate change mitigation behavior. This is also evident from the $\mathrm{F}$ value which has a probability value of less than $0.05(0.000<0.05)$. The contribution of environmental knowledge and environmental conservation responsibility for students to climate change mitigation behavior is $78 \%$, while the remaining $22 \%$ is influenced by other factors such as environmental perceptions, environmental awareness, motivation, age factors, social economy and other social environments.

\section{Discussion}

Knowledge is the amount of information in a person's memory that influences the way in which consumers interpret and assess the choices available. Conceptually, consumer knowledge can be divided into two components: objective knowledge and subjective knowledge [12]. Objective knowledge refers to the content and organization of knowledge (factual knowledge) stored in a person's memory. It refers to what an individual really knows about a 
type of product, problem, or object. Meanwhile, subjective knowledge refers to individual perceptions or judgments about what they know and how much they know about a product, problem, or object [13]. Based on the research results above, it can be obtained a probability value greater than $0.05(0.000<0.05)$. This means that environmental knowledge has a positive effect on climate change mitigation behavior.

The results of this study are in accordance with the research conducted by [13] which states that environmental knowledge has a positive and significant effect on purchase intention of green products. Environmental knowledge influences environmentally friendly behavior to prevent climate change because it is a variable that cannot stand alone and requires a variable that can link environmental knowledge variables with climate change mitigation behavior variables, because the higher environmental knowledge [14]. Then what will be influenced is the nature of the person's behavior to protect the earth's ecosystem.

According to [15], environmental knowledge is a series of ecological knowledge that individuals have about the environment. The better environmental knowledge possessed by consumers, the students will increasingly understand about the quality of environmentally friendly products and will increase their motivation to buy environmentally friendly products so that climate change mitigation will increase. Based on the results of statistical research above, it can be found that the probability value is smaller than $0.05(0.000<0.05)$. This means that the responsibility for environmental preservation has a positive effect on climate change mitigation behavior. The results of this study are the answers of each respondent to the question item on the variable of environmental responsibility. The higher one's environmental responsibility is, the more it will affect behavior in mitigating climate change [16].

The results of this study are in accordance with research conducted by [6] which states that environmental knowledge has a positive effect on environmental responsibility and mitigation behavior in the environment (climate change). Such as research by [15] which shows that the greater environmental knowledge that consumers have regarding environmental issues, the greater will be the purchase intention of products and the attitudes of consumers of environmentally friendly products. Increased environmental knowledge can also increase responsibility for environmental preservation.[4].

According to [8] attitude is a view of likes or dislikes by evaluation, feelings, and tendencies towards an object or idea. Based on the results of the statistical research above, the probability value $(0.000)$ is smaller than 0.05 . $(0.000<0.05)$. This means that environmental knowledge together with the responsibility for environmental preservation of students has a positive effect on climate change mitigation behavior. The results of this study are in accordance with research conducted by [13] which states that attitudes towards the environment have a positive effect on purchase intention for environmentally friendly products. Environmental knowledge is a series of ecological knowledge possessed by individuals regarding the environment [15]. The better the environmental knowledge possessed by consumers, the more aware these consumers will be about the quality of environmentally friendly products and will increase their motivation to buy environmentally friendly products. [16] defines that knowledge about the environment is a basic knowledge that a person has about everything that can be done and attempted to assist in environmental protection by facilitating their behavioral commitment to making green purchases $[5,14]$.

In general, environmental ethics cognition, perceptions of the environment and responsibility for environmental preservation both individually and collectively determine the level of environmental-friendly behavior of students [12]. When controlling for each independent variable, then among the three independent variables studied, the largest correlation coefficient is the relationship between environmental responsibility and environmentally sound 
behavior. For this reason, in an effort to improve environmentally sound behavior, it is necessary to prioritize increasing environmental ethics cognition and perceptions of the environment. Climate change mitigation are common problems that require the synergy of all elements of society, including the academic community. As academics, the community is eagerly awaiting future thinking about environmental problems because of course a good environmental quality will sustain a good life $[2,15]$.

Environmental issues were not a top priority and became a sub-agenda that eventually dissolved and sank into the broader campaign theme. Environmental issues that are included in the campus and environmental care activities of mainstream students are more temporary and reactionary, such as natural disasters, accidents in the forest or forest destruction by human activities. Although this environmental damage can lead to climate change. However, it has not yet reached the root of the environmental problems that are happening. This temporary activity will only cause hatred for those who damage the environment. Meanwhile, the main issue that causes pollutants in the atmosphere due to industry is increasing [10]. Therefore students as pioneers of climate change mitigation need to increase environmental knowledge to be more responsible for the sustainability of earth's life.

\section{Conclusion} drawn:

Based on the results of the data analysis carried out, the following conclusions can be

1. Environmental knowledge has a significant effect on students' climate change mitigation behavior. This is evidenced by the probability value less than $0.05(0.000<0.05) .2$. Student responsibility for environmental preservation has a significant effect on student behavior in mitigating climate change. This is evidenced by the probability value less than 0.05 $(0.000<0.05)$. 3. Environmental knowledge simultaneously with student responsibility for environmental preservation has a positive effect on climate change mitigation behavior. This is evidenced by the probability value smaller than $0.05(0.000<0.05)$.

\section{Acknowledgments}

Thanks to the chairman of the LPPM Jakarta State University, who has given moral support for the implementation of this research. Likewise, thanks to students at the Faculty of Engineering, Jakarta State University for participating as respondents.

\section{References}

[1] Noesan, Wiradjat:, Peran Perguruan Tinggi dalam Pengelolaan Sampah. Bandung Makalah Seminar Sosialisasi Pengelolaan Lingkungan Hidup Bagi Mahasiswa se-Jawa Barat.pp.5-10 (2004)

[2] Barthel F, Neumayer E : A trend analysis of normalized insured damage from natural disasters, Clim. Change 113(2):215-237, doi:10.1007/s10584-011-0331-2. pp.(2011)

[3] Bouwer LM : Have Disaster Losses Increased Due to Anthropogenic Climate Change? Bull Am Meteorol Soc 92(1):39-46, doi:10.1175/2010BAMS3092.1. (2011)

[4] Pielke RA Jr : Nine fallacies of floods, Clim. Change 42:413-438. (1999) 
[5] Zhang HX.: Climate Change and Global Water Sustainability In: Meyers RA, editor. Encyclopedia of Sustainability Science and Technology. New York: Springer; 2012. pp. 2061-78. (2009)

[6] Safford TG, Norman KC, Henly M, Mills KE, Levin PS:. Environmental Awareness and Public Support for Protecting and Restoring Puget Sound. Environ Manage. 2014;53(4):757-68. 11.1007/s00267-014-0236-8 (2012)

[7] Aman, A.H.L., Amran H., and Zuhal H..: The Influence of Environmental Knowlwdge and Concern on Green Purchase Intention The Role of Attitude as a Mediating Variable. British Journal of Arts and Social Sciences. Vol. 7. No.2. pp. 145-166. (2012)

[8] Barber., N., Christopher T., and Sandy S, :. Wine Consumers' Environmental Knowledge and Attitudes: Influences on Willingness to Purchase. Inernational Journal of Wine Research. Vol. 1. pp. 60-71. (2009)

[9] Angelovska, J., Snezana B. S., and Nina A. : The Impact of Environmental Concern and Awareness on Consumer Behaviour. Journal International Environmental Application and Science. Vol.7. No.2. pp.407-415. (2012)

[10] Haryanto, B., and Santi B. : The Role of Environmental Knowledge in Moderationg the Consumer Behavioral Processes toward the Green Products (Survey On the Green Product-mind in Indonesian). Review of Integrative Business and Economics Research. Vol.4. No.1. pp. 202-2015. (2014)

[11] Julina. : Determinan Perilaku Pembelian Ekologis dan Konsekuensinya terhadap Lingkungan: Perspektif Konsumen di Kota Pekanbaru Berdasarkan Kolektivisme, Perhatian terhadap Lingkungan, Efektivitas Konsumen, dan Kesediaan Membayar. Kutubkhanah Jurnal Penelitian Sosial Keagamaan. Vol. 16 No.2. pp. 114-127. (2013)

[12] Lee, E., Nam-Kyu P., and Ju H.H. :. Gender Difference in Environmental Attitude and Behaviors in Adoption of Energy-Efficient Lighting at Home. Journal of Sustainable Development. Vol.6. No.9. pp.35-51. (2013)

[13] Noor, N.A.M., Azli M., Azilah K., Cik Z.M.J. Norsiah M., Norazwa M., and Hayatul S.S. : Creating Green Consumers : How Environmental Knowledge and Environmental Attitude Lead to Green Purchase Behaviour? International Journal of Islamis: Marketing. Vol.3. No.2. pp. 107- 122. (2012)

[14] Prasad, Ravinesh Rohit: Tindakan mahasiswa dalam penanggulangan perubahan iklim: studi kasus di University of the South Pacific dan Universitas Negeri Malang /Ravinesh Rohit Prasad. Doctoral thesis, Universitas Negeri Malang. pp.120-138 (2019)

[15] Sarvestani, Ahmad Abedi. Environment Ethics Toward an Islamic Perspective. Department of Agriculture and Education, College of Agriculture, Shiraz University, Shiraz Iran. Journal IDOS Publications. pp.245-267(2008).

[16] Miler. And Taylor.,: Living in the Environmental : An Introduction to Environmental Science. Beirmont. California. pp.80-106 (1985) 